\title{
Geoelectric structure beneath limestones of the Sao Francisco Basin, Brazil
}

\author{
J. M. Travassos ${ }^{1 *}$ and P. T. L. Menezes ${ }^{2}$ \\ ${ }^{1}$ CNPq-Observatorio Nacional, 20921-400 Rio de Janeiro, Brazil \\ ${ }^{2}$ FGEL/UERJ, 20559-900 Rio de Janeiro, Brazil
}

(Received November 30, 1998; Revised June 16, 1999; Accepted July 6, 1999)

\begin{abstract}
A reconnaissance MT survey was conducted in the southern portion of the Sao Francisco Sedimentary Basin, Brazil, for mapping the subsurface structure. The objective was to provide a regional model and in helping to select areas to be further surveyed with seismics. The data collected at seven EMAP-style spreads of $500 \mathrm{~m}$, with an average spacing of $30 \mathrm{~km}$. The field procedure allowed for the correction of statics and the production of 7 inverted models, smooth representations of the regional structure as seen below each site. A 2-D forward model tested and refined the regional structure revealed by the inversions and yielded an earth composed of 4 main geologic units. A $100 \mathrm{ohm} . \mathrm{m}$ limestone layer on the top of $20 \mathrm{ohm} . \mathrm{m}$ shales, followed by a 1000-200 ohm.m structured basement. Crustal resistivities do not change until reaching depths of more than $30 \mathrm{~km}$. The model ends at a conductive half-space of $30 \mathrm{ohm} . \mathrm{m}$. A suture zone between an orogenic belt and the Sao Francisco craton was modeled below the sedimentary section bringing its know limits $60 \mathrm{~km}$ to the east.
\end{abstract}

\section{Introduction}

Electromagnetic methods (EM) play a minor role in hydrocarbon exploration. They cannot yield a result with a comparable accuracy and spatial density as achieved by reflection seismic. Yet they rank second to seismic methods for their resolution and depth of penetration. Moreover EM methods are often well suited to exploration problems arising due to high-velocity rocks (e.g., limestones, salt and volcanics) or due to complex thrust and basin range geologic environments. In cases where high-velocity rocks are also highly resistive the contrast with the surrounding sediments can be more than one order of magnitude making those environments good electrical targets.

EM methods can be used in a reconnaissance survey or in conjunction with seismics or other methods. The combined use of EM and seismic data can provide a different insight into exploration problems. In reconnaissance surveys EM methods can provide an inexpensive way of testing hypothesis before starting a seismic survey. Used in conjunction with reflection seismics they may resolve ambiguities in some cases.

Among the EM techniques the magnetotelluric (MT) method has been widely used as an aid to petroleum exploration for several decades. The reliability of the MT method has improved due to advances in data acquisition (instrumentation and field layout), data processing and 2-D/3-D forward and inverse modeling codes. In terms of field layout the two most important advancements were the introduction of a remote reference (RR) to reduce the bias associated with

*Formerly at Lamont-Doherty Observatory, Palisades, NY 10964, U.S.A.

Copy right(C) The Society of Geomagnetism and Earth, Planetary and Space Sciences (SGEPSS); The Seismological Society of Japan; The Volcanological Society of Japan; The Geodetic Society of Japan; The Japanese Society for Planetary Sciences. noisy magnetic field site (Gamble et al., 1979; Clarke et al., 1983 ) and the electromagnetic array profiling (EMAP) to remove the ubiquitous static shift effects (Torres-Verdin and Bostick, 1992a,b). Static effects are caused by the presence of small-scale bodies in the near-surface. Static effects are noticeable at periods where skin depths are much larger than the causative body. Those effects manifest themselves as a shift of apparent resistivity curves. Phase is not affected.

The most important element in impedance estimation was the introduction of the robust methods. The robust methods can yield reliable impedance estimates in the presence of a moderate number of violations of the assumptions of Gaussian distribution and in the presence of nonstationary noise. Most of these methods are based on an iterative reweighted least squares scheme and may include data substitution (Egbert and Booker, 1986; Chave et al., 1987; Chave and Thomson, 1989, 1992; Larsen, 1989; Sutarno and Vozoff, 1991; Larsen et al., 1996). In addition MT has highly developed modeling capability that includes 3-D modeling (Dey and Morrison, 1979; Wannamaker et al., 1984, 1987; Wannamaker, 1991; Mackie et al., 1993).

The data shown in this work is part of a somewhat larger work done for Petrobras, the Brazilian State Oil Company, on the Sao Francisco Basin, in a reconnaissance effort before the start of a seismic campaign. The interest on hydrocarbon exploration in the Proterozoic is recent in Brazil. It started in the 70's when gas was found in a water well. Three wells were subsequently deployed based on a regional geologic mapping done in 1984-1986. The wells found gas (90\% methane, $2 \%$ ethane and traces of propane) in a senile stage at $90 \mathrm{~m}$ depth (Braun et al., 1990). The source rocks have a thickness of $500 \mathrm{~m}$ and the organic material is basically algae (Braun et al., 1990). The Sao Francisco Basin has about the same age and geology as other oil producing basins else- 

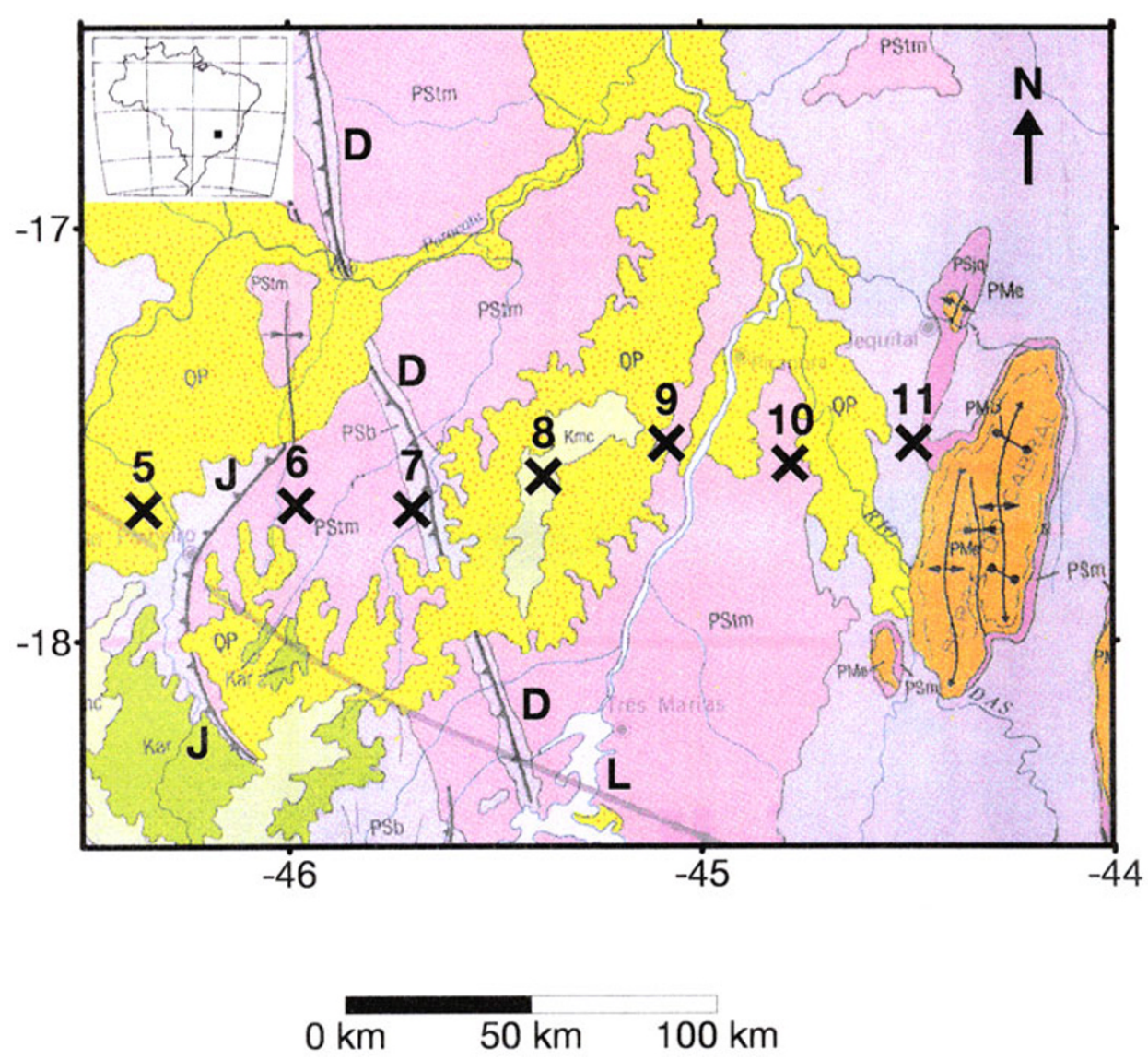

Fig. 1. Localization of the MT sites ( 5 to 11) superimposed on the Geological map of the survey area (CPRM, 1995). The black square in the inset shows the localization of the mapped area in Brazil. $\mathrm{J}$ is the Joao Pinheiro fault and D is the Sao Domingos fault. L is a mapped magnetic lineament. The geological units traversed by the MT profile range from Quaternary clastic sediments (QP) and Mesosoic sandstones (Kmc) to the Proterozoic arkoses and limestones of the Bambui Group (PStm and PSb), stopping short of the quartzites of the Cabral Range.

where in the world, such as Irkutsk (Russia) and Officer and Amadeus (Australia) (Murray et al., 1980). A main difference here is the absence of evaporite sequences in the Sao Francisco Basin. The geophysical knowledge of the basin is scarce and scattered. A review of the work done in the area can be found in the literature (Ussami, 1993). No other geophysical data are available in the area covered in this work. But elsewhere in the basin there are some gravimetric data (Blitzkow et al., 1979; Lesquer et al., 1981; Assumpcao et al., 1984; Ussami, 1986; Ortu, 1990) and refraction seismics (Knize et al., 1984; Berrocal et al., 1989). Accordingly to those last two works the Moho is estimated to be at $43 \mathrm{~km}$. A seismic tomography study done just over $300 \mathrm{~km}$ due south of the studied area has estimated the basement of the basin to lie at $2.8 \mathrm{~km}$, below the Brasilia mobile belt (Marchioreto and Assumpcao, 1997). There are many isolated aeromagnetic surveys on the basin but no regional interpretation that consolidates the information (Ussami, 1993). There is another MT survey about $150 \mathrm{~km}$ north of the survey area where the interpretation was based entirely on 1D inversions (Porsani and Fontes, 1993).

\section{Survey Area}

\subsection{Geology}

The foreland Sao Francisco Basin is located in the northeastern part of Brazil spanning over $216,000 \mathrm{~km}^{2}$. Its main sedimentary group is the upper Proterozoic Bambui Group, a sequence laid on a carbonate platform sculptured onto a complex basement (Braun, 1982). Basement rocks are mostly Archean migmatites and granitoids of the Sao Francisco craton and middle Proterozoic highly folded metassediments of the Arari (siltstones and quartzites) and Espinhaco (quartzites) supergroups. The Bambui Group covers most of the Sao Francisco craton and is affected by the tectonicmagmatic events associated with the Brazilian orogeny $(650$ $550 \mathrm{Ma}$ ). The Bambui Group is divided into the upper Tres Marias formation (arkoses) and Paraopeba subgroup (carbonates).

Figure 1 shows a geologic map of the survey region on a 1:2,500,000 scale (CPRM, 1995). The profile traverses over Quaternary clastic sediments, late Proterozoic arkoses and limestones of the Bambui Group, stopping short of the middle Proterozoic quartzites of the Cabral Range. The Bambui Group displays on its western limit a highly folded domain bounded by a subvertical reverse fault: the Sao Domingos fault (see Fig. 1). From that fault to the east the subsurface is flat-layered except for some confined domains which become more frequent to the east and southeast of Fig. 1. These folds remain less intense than to the west. Fractures basically group in two systems: NNW and NE. The western side is more fractured and displays Appalachian-like folding belts. Those faults display high dip angles and a rectilinear signa- 
ture due to a compressive stress regime (Braun, 1982). This stress regime has actuated since the beginning of the Bambui deposition, due to stress on the craton as represented by the Proterozoic heavily folded Brasilia mobile belt (Valeriano, 1992). The present knowledge on the basin indicates that the deposition of the Bambui Group occurred on a foreland basin with origin in the tectonic buildup that resulted during from the compressive stress regime represented by the Brasilia mobile belt (Proterozoic) on the Sao Francisco craton (Archean) (Thomaz et al., 1998).

\subsection{Site location and layout}

The data set of this work was collected along a $207 \mathrm{~km}$ long EW MT profile as seen in Fig. 1. The profile was designed to be perpendicular to the known geological strike. The 7 remote referenced sites were obtained with equipment manufactured by EMI Inc. All sites were recorded broadband covering the range from $10^{3}$ to $10^{-3} \mathrm{~Hz}$. Sites were spaced 30 $\mathrm{km}$ on average. A remote site was deployed at a distance of 20-30 km away from any given site. Each site was laid out as a EMAP-like spread with 5 contiguous dipoles along profile direction, namely the $x$-direction, and 1 perpendicular dipole along the $y$-direction. All dipoles are $100 \mathrm{~m}$ long, rendering a $500 \mathrm{~m}$ long EMAP spread at each location. Each dipole along the $x$-direction is numbered sequentially from west to east as: $1, \ldots, 5$. The $y$-dipole is deployed somewhere along the spread. The magnetic field vertical component was not recorded because all available channels were used to record the horizontal field components. Figure 2 shows the field layout used for site 11: the $y$-dipole was deployed between $x$-dipoles 2 and 3. Assuming the electric field along the $y$ direction does not vary too much each setup is equivalent to 5 contiguous remote reference sites. Each of the 5 subsites is obtained combining a particular $x$-dipole, from 1 to 5 , with the $y$-dipole. Note the whole profile is then equivalent to 35 remote reference sites with uneven spacing. Infield data processing (for single site only) allowed an efficient data quality assessment. The production rate averaged 1.3 sites a day for a crew of 4-5 people.

\section{Data Processing}

At each site $n, n=5, \ldots, 11$, the coupling between the local electromagnetic field components is given by

$$
\left[\begin{array}{c}
E_{x}^{(i, n)} \\
E_{y}^{(n)}
\end{array}\right]=\left[\begin{array}{cc}
Z_{x x}^{(i, n)} & Z_{x y}^{(i, n)} \\
Z_{y x}^{(n)} & Z_{y y}^{(n)}
\end{array}\right] \cdot\left[\begin{array}{l}
H_{x}^{(n)} \\
H_{y}^{(n)}
\end{array}\right]
$$

where $i=1, \ldots, 5$, refers to a particular dipole along the $x$-direction. The estimation of the earth's response functions was carried out in the frequency domain using a robust code (Egbert and Booker, 1986). The overall data quality was good for all frequency bands. Figure 3 shows the apparent resistivity and phase values for the subsite $(i=1, n=6)$. This subsite of site 6 displays a 2-D behavior due to its proximity to a more resistive region to the west, limited by the Joao Pinheiro fault (see Fig. 1).

The regional impedance tensor is distorted by an unknown, frequency-independent real tensor that characteristically mixes the phases representing the expected 2-D regional structure (Jiracek, 1990). Correction techniques for these effects assume a 3-D heterogeneity over a 2-D regional structure. The recovery of the regional structure can be obtained

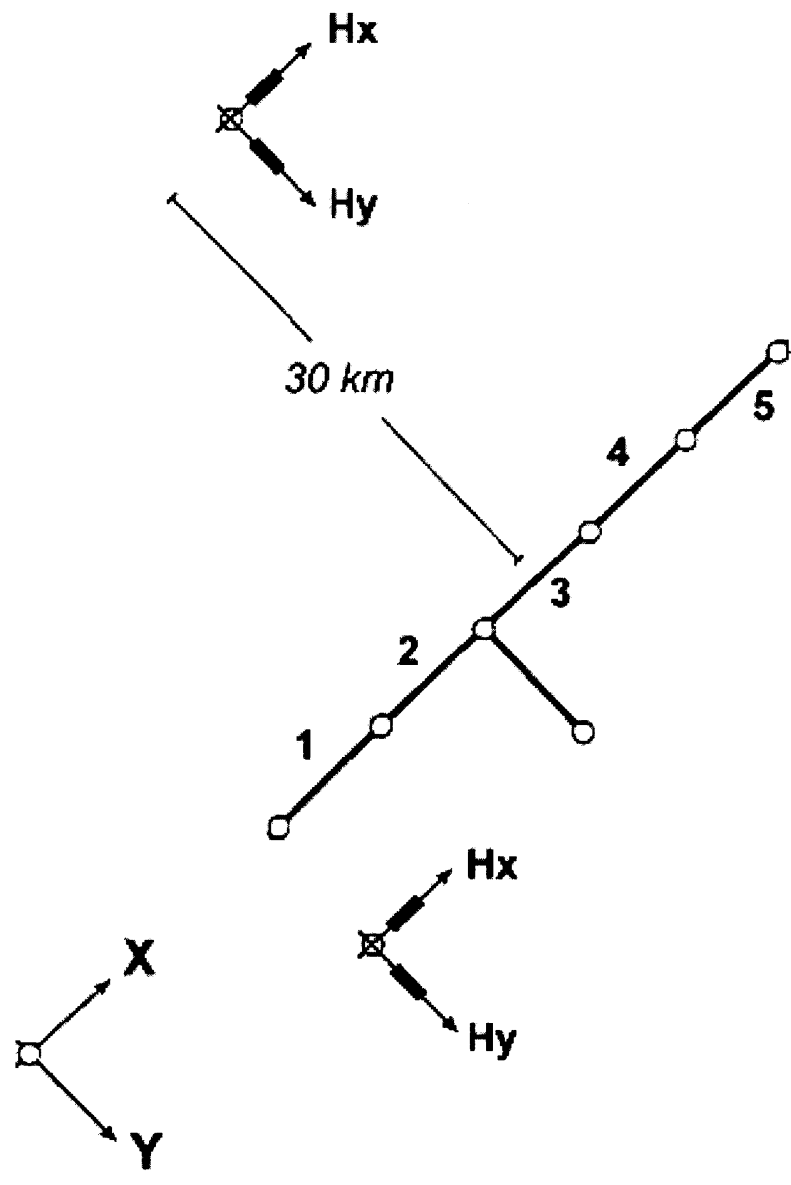

Fig. 2. Field layout of site 11 . The $x$-direction is coincident to the profile direction. Dipoles along the $x$-direction are numbered west to east. The remote site is located $30 \mathrm{~km}$ away from the site.

from the decomposition of the MT impedance tensor (Groom and Bailey, 1989; Bahr, 1991; Groom and Bahr, 1992). In this work we have used the GB decomposition (Groom and Bailey, 1989) to yield a 2-D regional tensor. The analysis of the impedance and the distortion parameters (twist, shear and strike) was done at different periods. The authenticity of the model, i.e., a local 3-D distortion superimposed to a regional 2-D model is tested with a chi-square test (Chave and Thomson, 1989). The obtained regional geoelectric strike is selected as the one producing the smallest frequency-independent misfit in relation to the distortion model. This analysis showed a negligible distortion at all sites along the profile with an average regional strike along the NS direction. On average the GB regional strike was less than 3 degrees off the NS direction, in fully agreement with the geologic knowledge of the area. We then elected to orient the tensors along the NS regional strike. The twist and shear were allowed to vary against period at each subsite. The variability of both twist and shear was small at all sites, -3.4 and -0.7 on average. Then they were fixed to a constant value at which they displayed a near independent behavior for the entire period range at each subsite. The fixed values of strike, twist and shear were used to recover the regional impedances. 

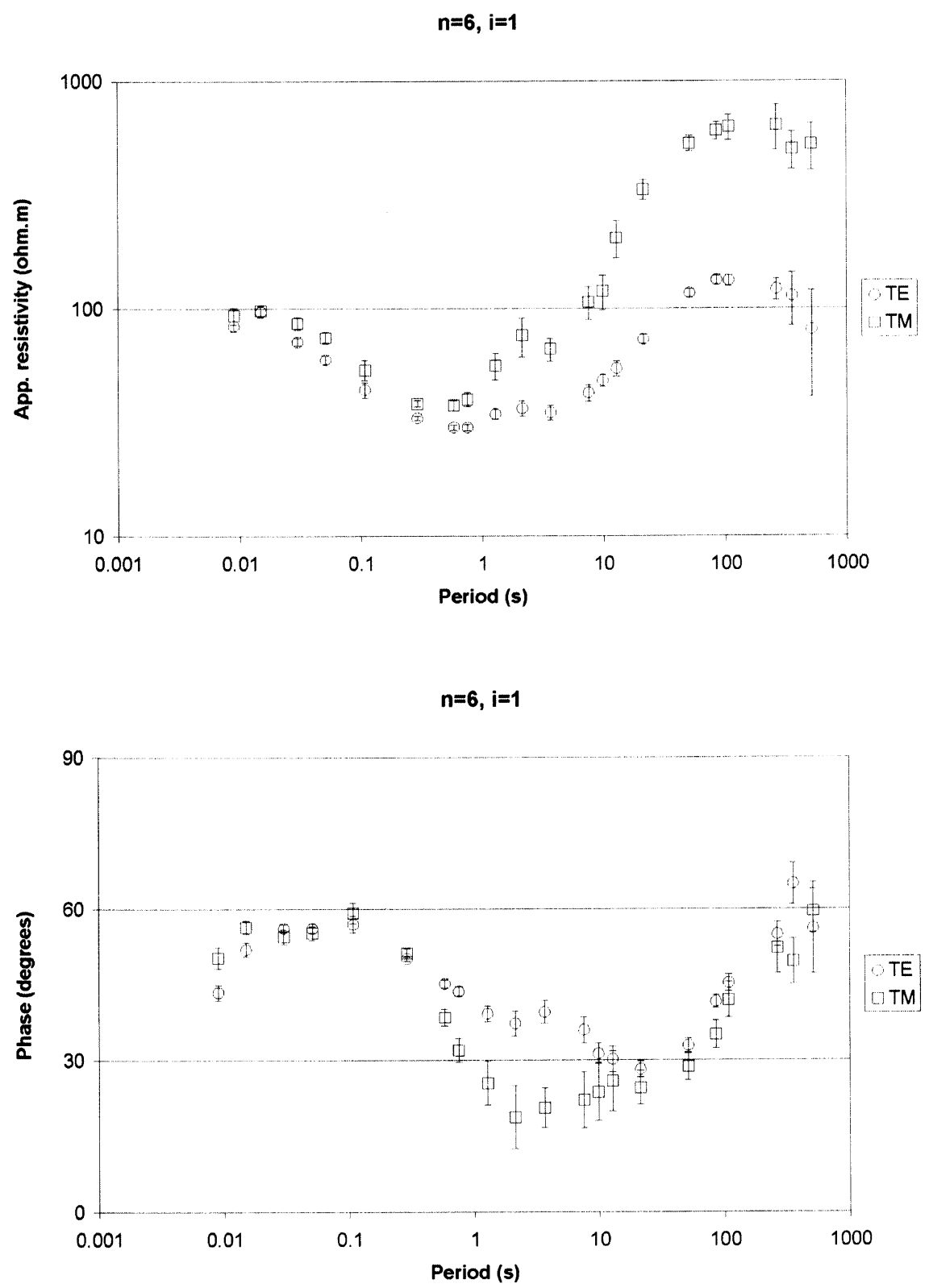

Fig. 3. Apparent resistivity and phase at subsite $(i=1, n=6)$ of site 6 . TE estimates are shown as circles and the TM as squares. Error bars correspond to a $95 \%$ confidence interval.

\section{2-D Inversion and Static Correction}

The following analysis is done on the recovered GB 2-D regional impedances obtained as described in the last section. At this point the phases express the regional model but both site gain and anisotropy may still affect the resistivity values. There are a number of ways to correct for the static shift phenomenon whereas anisotropy can be solved through modeling. The static shift may be corrected if one has a sufficiently dense MT spatial coverage: the EMAP technique is designed to deal with such distortion (Torres-Verdin and Bostick, 1992a,b). Sometimes even isolated sites can be used as long as all sites resolve at least one regional feature (Jones, 1988). In this case apparent resistivity curve shifting (Jones, 1988) and/or an inversion effort with the gain factors free at each site may be used (Chouteau et al., 1997). Simple curve shifting assumes no intrinsic anisotropy. Other way to correct for static shift effects is to resort to independent geophysical data, e.g., electrical or electromagnetic field data (Pellerin and Hohmann, 1990; Chouteau et al., 1997).

None of those are applicable to the present data set. Sites are spaced $30 \mathrm{~km}$ on average, too isolated to allow the correction of static shift using the data from neighboring sites or the estimation of a reference value for the apparent resistivity curves. On the other hand there is no independent data either. EMAP spatial filtering (Torres-Verdin and Bostick, 1992b) cannot be used within the spreads as depths of interest are well over their lateral dimension.

In this work we take advantage of the continuous field layout of 5 subsites at each site to correct for static distortions. We assume that the $E$-polarization electric field $\left(E_{y}\right)$ does not change too much along a spread to allow the use of expression (1), i.e., the equivalence to 5 contiguous remote reference MT 

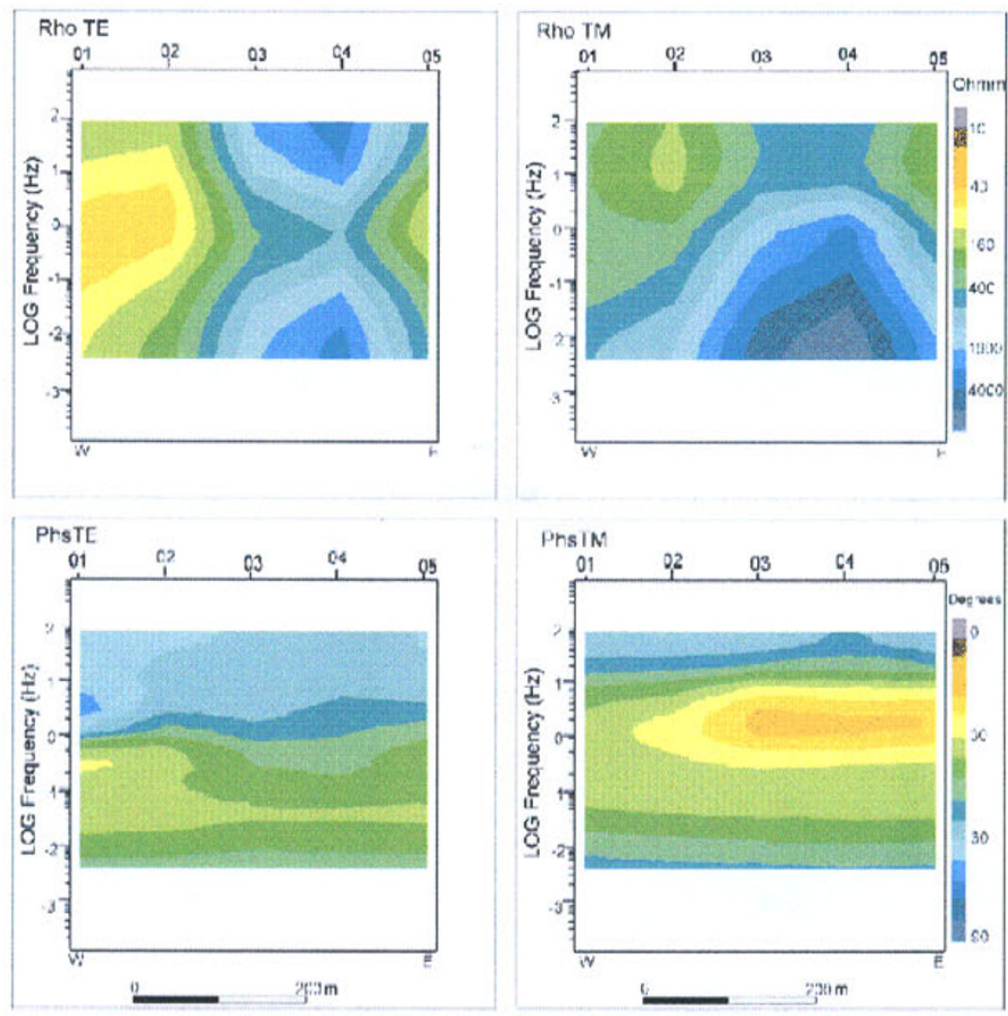

(a)
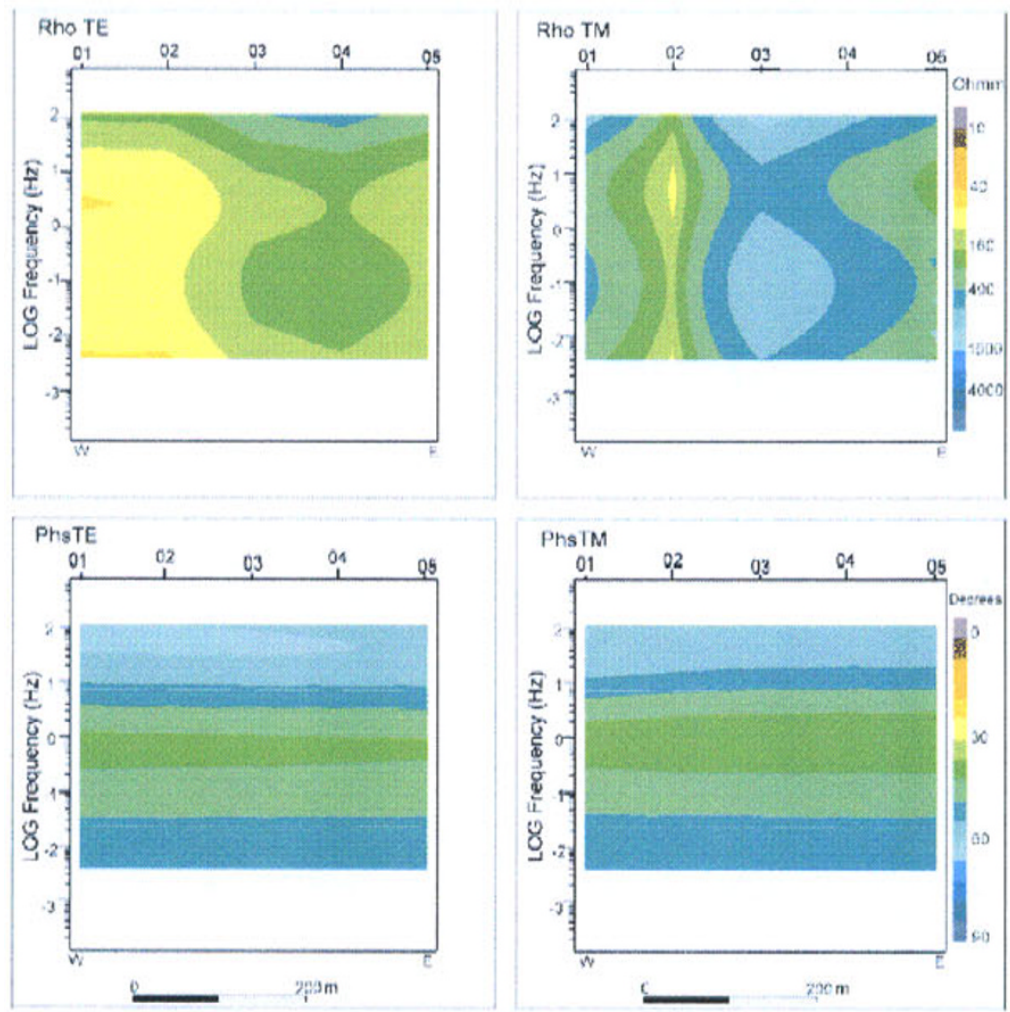

(b)

Fig. 4. Pseudosections of data and inverted responses at site 11. There are 2 groups of 4 panels in this figure. Data pseudosections are in the top 4 panels, in the group labeled (a). Inverted responses pseudosections are in the bottom 4 panels, in the group labeled (b). TE polarization is shown on the first column of panels, and the TM polarization is shown on the second column of panels. 


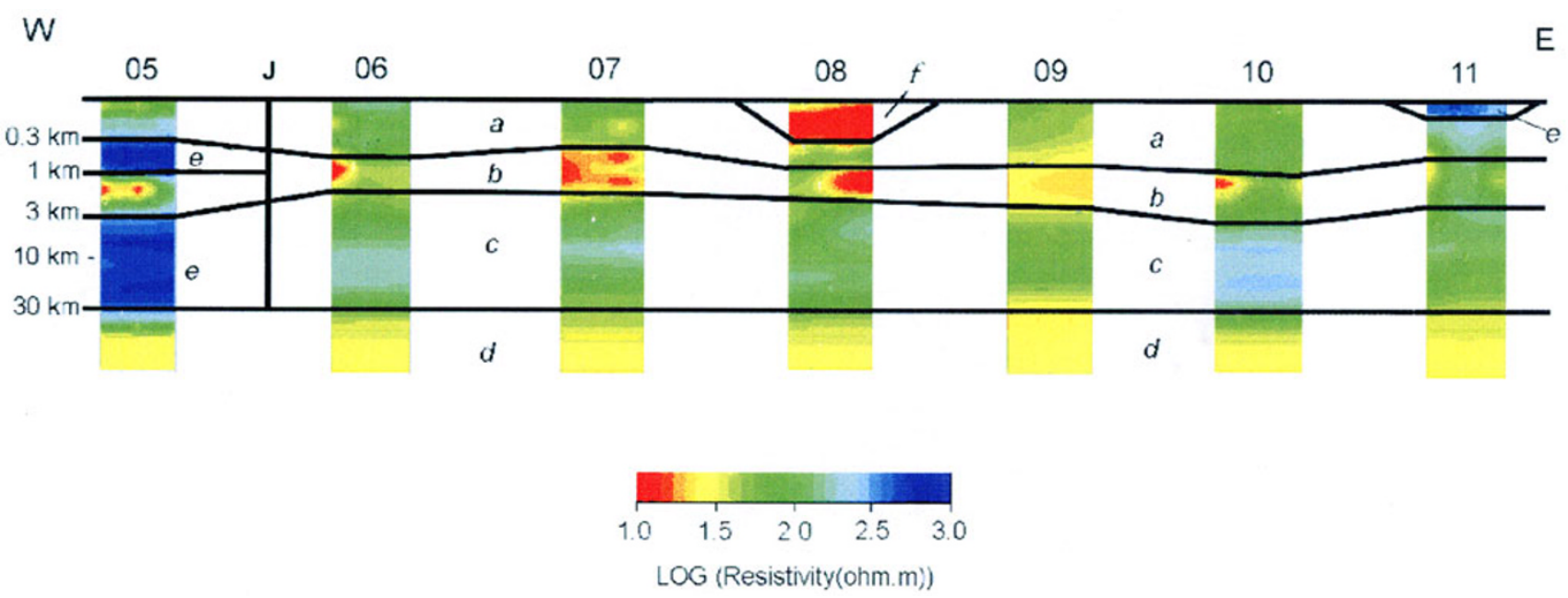

Fig. 5. Continuity section for the whole profile. All inverted 2-D models are assembled together to produce this section. The heavy lines superimposed on the inverted models are the boundaries used in the first forward 2-D model. J is the Joao Pinheiro fault. The first model has the following resistivities: (a) $100 \mathrm{ohm} . \mathrm{m}$, (b) $20 \mathrm{ohm} . \mathrm{m}$, (c) $200 \mathrm{ohm} . \mathrm{m}$, (d) $30 \mathrm{ohm} . \mathrm{m}$, (e) $1000 \mathrm{ohm} . \mathrm{m}$, and (f) $10 \mathrm{ohm} . \mathrm{m}$.

sites. Assuming further that an impedance decomposition was performed correctly, the subsites will be related to each other along the $x$-direction. Now we have 5 subsites with an adequate spatial sampling that makes possible the correction of static shift.

Three sites displayed important local variations along the $x$-direction, sites 5,8 and 11 . This is a result of the spatial variation along the profile in both local and regional scales. Figure 4(a) shows the apparent resistivities and phases for both polarizations at site 11 (refer to Fig. 1) where local spatial variability is the most drastic. The figure shows inductive responses and, maybe to some extent, galvanic effects along the spread of site 11 . Site 11 sits on quartzites of a basement outcrop and its data have distinct characteristics from all other sites.

Local scale spatial variability at a given site and static shift effects can be both dealt with the field procedure adopted in this work. Both effects may affect most of the sounding curves at a particular site masking the regional model. Five out of seven sites showed indications of being affected by static shift at least for some extent of the frequency range. We assume any static distortion would be caused by small, in relation to the total length of a site, randomly distributed and oriented inhomogeneities in the survey area. Tensor decomposition can deal with the spatial variability at local scale. Both corrections take advantage of the denser coverage along the stride of a given site.

RRI inversions (Smith and Booker, 1991) were performed at each of the 7 sites using the regional response functions as recovered from the GB decomposition. Apparent resistivity and phase data for both polarizations at the 5 dipole combinations of each spread were inverted together. Both polarization resistivity curves were allowed to shift freely during inversion. The static shift parameter, $g$, was adjusted within each site. This procedure produced 7 smooth 2-D inverted models, together with their responses and static shift parameters. Convergence was reached after 8-30 iterations of robust inversion at all sites along the profile. We used $\alpha=4$ and $\eta=1.5$ in the penalty function for all inversions (Smith and Booker, 1991). Note the inverted models are more a compromise between what one could get inverting the two modes independently. A joint inversion cannot achieve misfits as small as the ones obtained through the inversion of each mode (Wu et al., 1993). This is hardly an issue here as each inverted model will be used to contribute only with its main features to the interpretation stage. Our main interest is to derive a regional model and not a local model at each site. Retrieving just the local geoelectric structure below each site is of very limited interest.

Each inverted model is a smooth representation of the regional structure below a particular site. They are like small windows open to the broader regional structure that can be used for a first interpretation. Assuming each site retains the main features below it should be possible to produce a regional interpretation on the combined information of all inversions. This has to be done with caution as some the observed spatial variation at the local scale are important at some sites. Figure 4(b) shows the response of the RRI inversion at site 11 for both TE and TM modes. Figure 4 shows that the inversion at site 11 produced a smoother version of the subsurface in relation to what is seen by the data. The inverted model responses retain the lateral resistivity transition conductor to resistor along the length of the site. This occurs between dipoles 02 and 03 . Inverted phases tend to be higher than regional ones but are still compatible in broad terms.

In order to use the inverted models to produce a regional model, we assembled together all the RRI inversions along the profile. Such procedure allowed us to infer any lateral continuity that may exist among the 2-D inverted models. This produces the continuity section shown in Fig. 5. In order to estimate the limits on the resistivity distribution we concentrated on the resistivity regimes that persisted from site to site. We then inferred the initial boundaries between resistivity regimes as seen in Fig. 5. Available geological information and the nearest resistivity log data, some $100 \mathrm{~km}$ 
north of the profile were used to aid in this task. It is assumed here that the boundaries inferred in the continuity section can reproduce the main regional, i.e., long wavelength, features along the profile.

Based on the model shown in Fig. 5 the layered structure of the basin is composed of 4 main geoelectric units. A resistor unit of $100 \mathrm{ohm} . \mathrm{m}$ on the top of a conductor of $20 \mathrm{ohm} . \mathrm{m}$. A resistive zone of 1000-200 ohm.m follows those units. This resistive zone extends down to about $30 \mathrm{~km}$ where there is a transition to a conductor of $30 \mathrm{ohm} . \mathrm{m}$. That transition is particularly clear at sites 05 and 10 . Three sites display a more involved structure: 05,08 and 11. Site 05 sits on a more resistive region of $1000 \mathrm{ohm} . \mathrm{m}$, probably associated to the Brasilia Mobile Belt rocks. The limit between this high resistor and the more conductive rocks to the east is inferred as the Joao Pinheiro fault. The shallow conductor at site 08 is probably associated to mapped sandstones. The shallow resistor at site 11 are quartzites that were locally mapped. Resistivity regimes and their boundaries show variations from site to site. Therefore the adopted values depend on how we look at the smooth transitions of the inverted models. This is as far as we can go with the first model shown in Fig. 5.

\section{2-D Modeling}

The initial model shown in Fig. 5 can be regarded as a first approximation to recover the regional structure based on the 2-D inversions and on the limited independent geological and geophysical data available. The regional features of that model can be further tested and eventually refined with 2-D forward modeling. The modeling exercise was done using a finite element algorithm (Wannamaker et al., 1987). The validity and sensibility of our model can be assessed comparing model responses to the observed data. The objective of the modeling exercise was to produce a minimum structure that is still able to explain the regional impedances. The forward model will necessarily incorporate both regional (long wavelength) and more localized features eventually needed to locally improve the fit of model responses to the data. In particular shorter wavelength features as the shallow conductor at site 8 and the resistor below site 11 were tentatively included in the initial forward model.

Figure 6 shows the final 2-D model for the regional profile. The main features revealed by the model are the delimitation of the Sao Francisco basin basement at $3 \mathrm{~km}$ depth and the limit of the Brasilia mobile belt at the Joao Pinheiro fault. Several other important geoelectrical features reveal important geological data. The resistive rocks of the basement overlay a conductive layer at a depth of $35 \mathrm{~km}$. The thickness of the conductor cannot be resolved so we use it as a half-space to terminate the model. We depicted its lower limit in Fig. 6 to be within one skin-depth at the longest period. As a half-space we can speculate that the conductor may sink to greater depths, below the resistive rocks of the Brasilia mobile belt, i.e., down to $70 \mathrm{~km}$, as shown in Fig. 6 . Although this interpretation is far from being conclusive it is compatible with the inverted model at site 5, see Fig. 5.

Some shallower features above the basement were incorporated in the model in order to improve the fit of model responses to the data. Those features are in the blow up of the first $3 \mathrm{~km}$ of the model, shown in Fig. 7. The Sao
Francisco basin is confined in this first $3 \mathrm{~km}$. The contrast in resistivity provided by the conductive sediments below the first resistive layer permits the delineation of some features within the basin. The resistive layer is thicker towards the east and now its boundaries are better resolved in relation to the first model of Fig. 5. A high in the resistive basement below sites 08 and 09 was also required by the model. It was not possible to model the shallow conductor below site 8, seen in Fig. 5.

One of the most difficult features to model in the observed data was a splitting in the apparent resistivity curves at about $1 \mathrm{~s}$ at most sites. See the upper panels of Fig. 4(a) for site 11. This splitting might be associated to a highly structured basement and to the intense faulting in the region. That faulting is clearly mapped at scales of 1:250,000 and 1:500,000. Based on previous modeling exercise in another sedimentary basin in Brazil (Beamish and Travassos, 1993) we postulated the existence of vertical resistive structures $1 \mathrm{~km}$ thick with 100 ohm.m near each site extending to the top of the basement. Model responses are not very sensitive to changes either in the thickness or in the resistivity of those structures, it is only required that they are resistive in relation to the sediments in the basin. The structures were required to improve the fitting of the TM responses to the data, allowing the comparison between model responses and data. We did not include those structures in Fig. 7 nor we used them in our interpretation. No further attempt to fit any finer data signature was tried, as the profile is too sparse.

The assessment of the trial-and-error exercise of fitting model responses with the observed data has to be done with a subset of the data. We cannot use all the 5 subsites at each site for this because a regional model cannot reproduce the observed lateral variability within the limits of a given site as seen in Fig. 5. There are a few choices. One would be to estimate average sounding curves as representative of each site. This would have introduced an unknown amount of distortion on the averaged sounding curves due to the contribution of both signal and geological noise in each individual sounding curve. Another way is to choose one particular subsite at each site. We chose one of the two $x$-dipoles closest to the $y$-dipole at each of the 7 sites (refer to Fig. 2). We preferred the pair that displayed the lowest noise level in the sounding curves. This makes the profile shown in Fig. 1 as if it were composed of a single remote-reference MT site at each of the 7 locations. The choice of a representative subsite at each location keeps noise at the observation levels. The trial-and-error fitting of model responses was repeated until a reasonable fitting to the data was achieved. This minimum structure constitutes our best guess of the regional structure based on the limited amount of geophysical data available. We expect that the boundaries and resistivity regimes are representative of a broad spatial average of the true geoelectric structure.

Figure 8 shows a comparison between model response and data for both TE and TM modes. Data were static shift corrected using the factors estimated in the inversion stage. The TM responses display a better fit than their TE counterparts but the quality of the results indicate that the simple model shown in Fig. 6 is able to explain most of the data characteristics. The poorest fit is seen in the phase for the TE mode. 


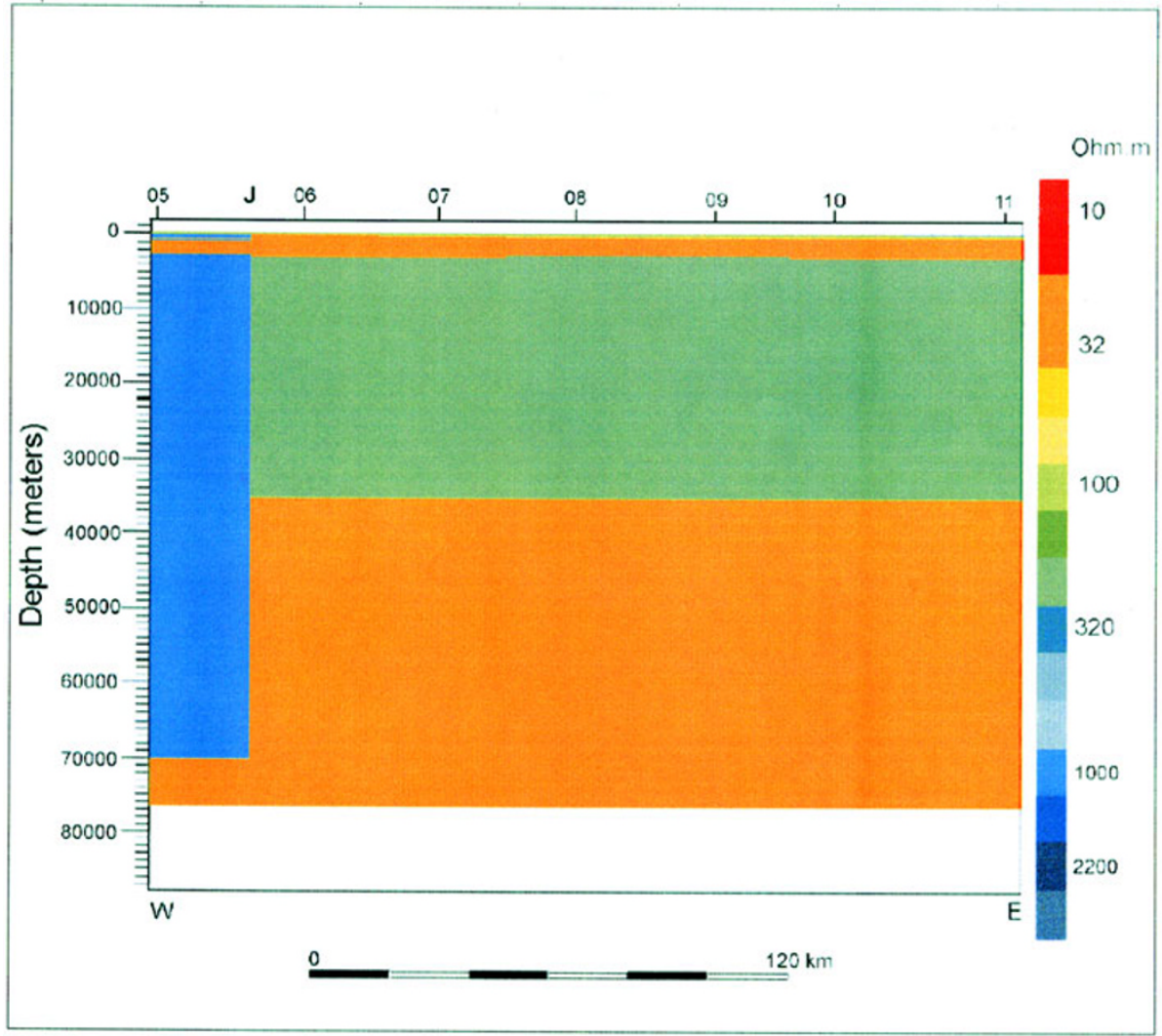

Fig. 6. Geoelectric model for the whole MT profile. J is the Joao Pinheiro fault. The lower limit of the model cannot be resolved by the data.

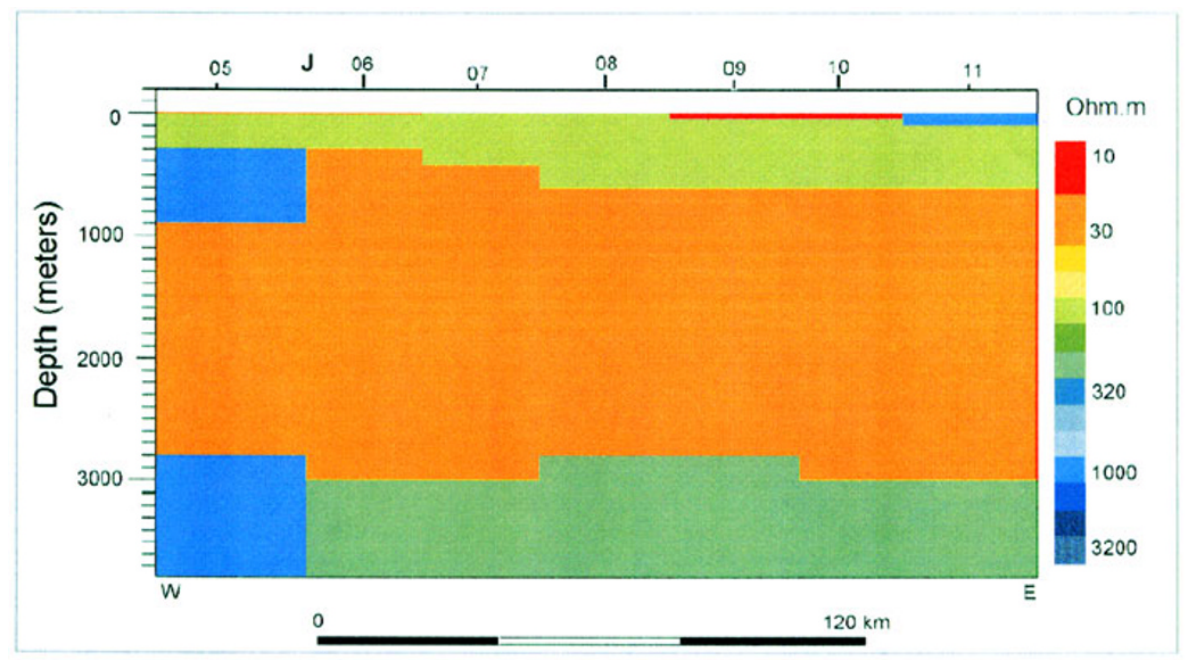

Fig. 7. Blow up of the first $4 \mathrm{~km}$ of the geoelectric model shown in Fig. 6. J is the Joao Pinheiro fault.

An inspection on Fig. 8 shows that we can be confident about the minimum structure geoelectric model for the region.

\section{Interpretation}

The geoelectric model shown in Figs. 6 and 7 allow us to draw a number of conclusions that shed some light on the geology of the studied region. Model results are expected to recover some of the geoelectric structure as any spatial wavelengths that are not compatible with site spacing can- not be recovered. We restrict ourselves in our interpretation on the long wavelength features, disregarding the localized bodies. For instance boundaries like the top of the basement that is expected to be highly structured (Alkimin et al., 1993; Braun et al., 1990) appear flatter than they should be. But any wide-spaced MT survey suffers from some degree of aliasing. Therefore we regard the boundaries between resistivity regimes as broad averages. Note that the inversions along $500 \mathrm{~m}$ at each site are able to recover structures within their 

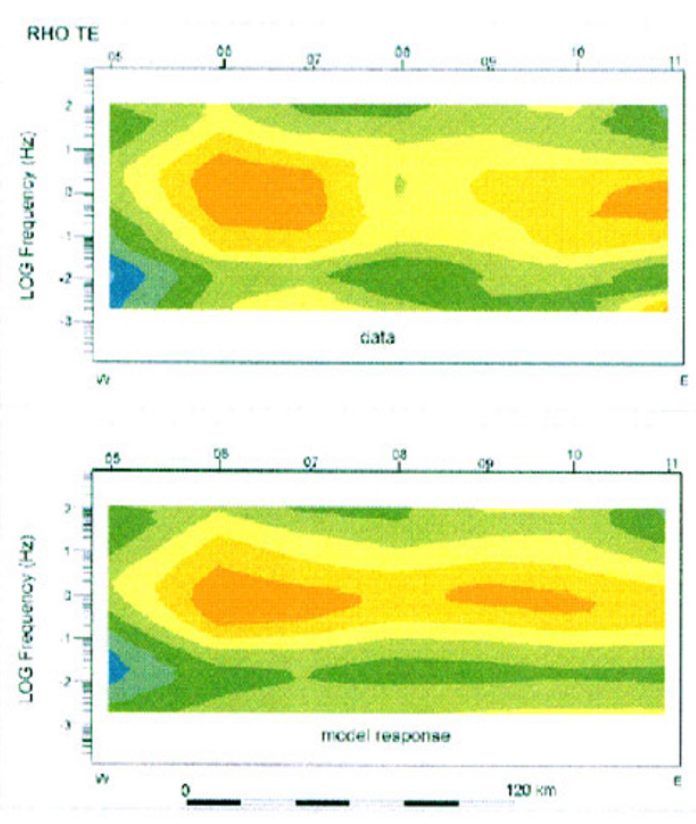

(a)
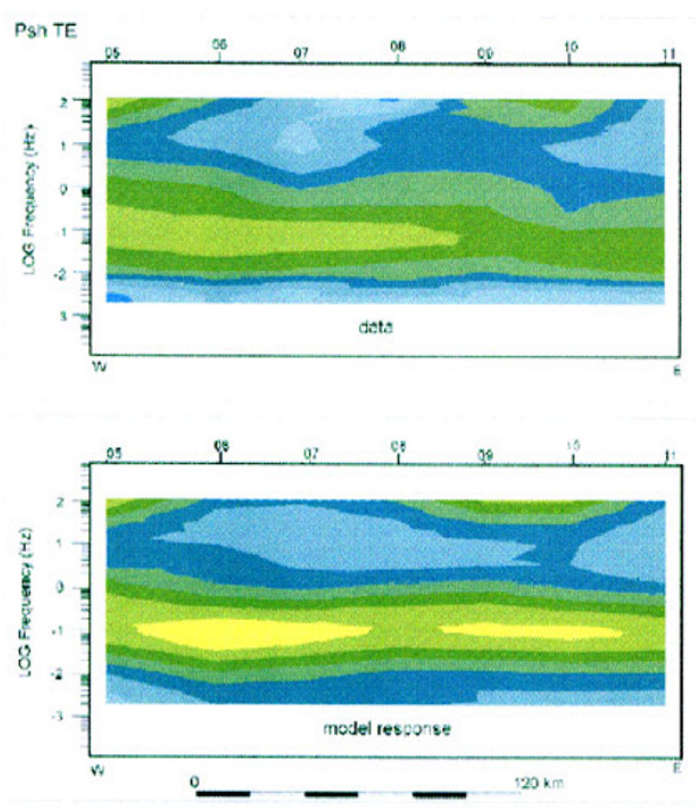

(c)
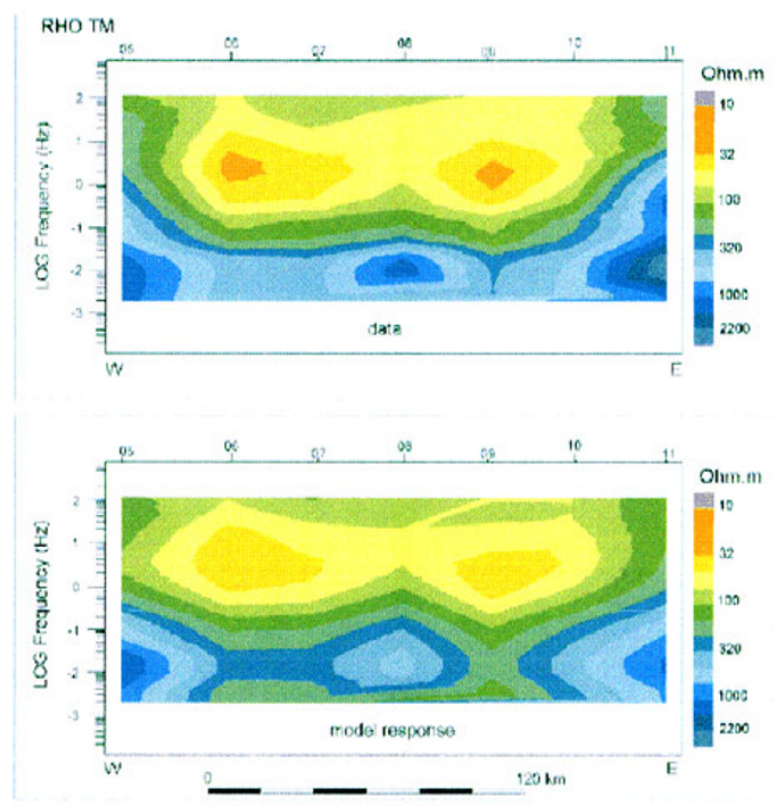

(b)
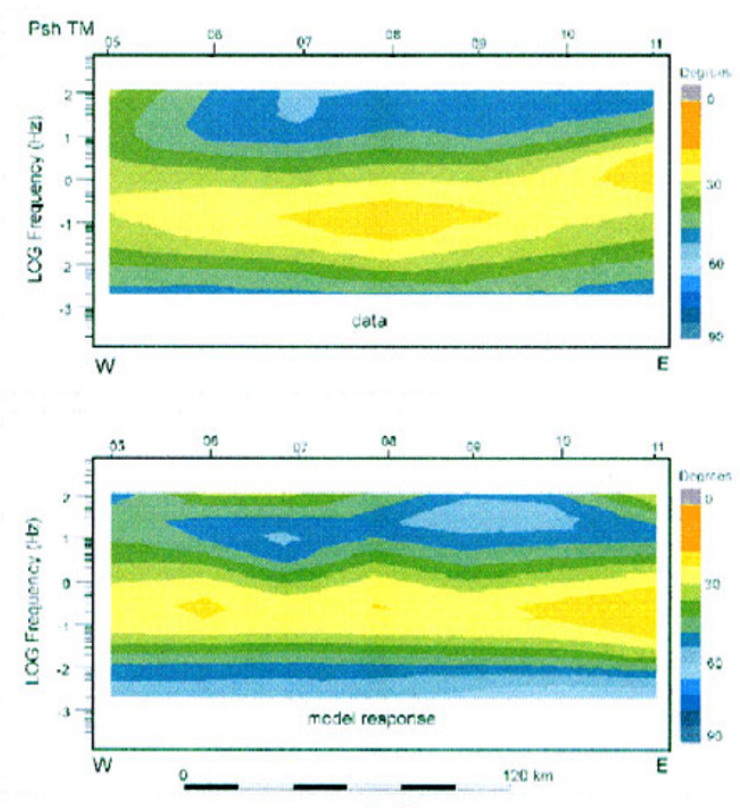

(d)

Fig. 8. Comparison between the static shift corrected data and model responses. There are 4 groups of 2 panels. The top 2 groups show the apparent resistivities for the TE (a) and the TM (b) polarizations. The bottom 2 groups show the phases for the TE (c) and the TM (d) polarizations. Upper panels show the data and lower panels show model responses.

reach with no aliasing in relative terms but on the other hand, they are of very limited interest in themselves.

The ubiquitous Sao Francisco basin limestone cover (100 ohm.m) is clearly outlined, thickening from west (300 m) to the east $(800 \mathrm{~m})$. Below sites 09 and 10 there is a surficial thin conductive layer of $10 \mathrm{ohm} . \mathrm{m}$ associated to Paleozoic sediments. There is a stratigraphic inversion below site 11 probably due one of the numerous reverse faults in the region. The thin resistor of $1000 \mathrm{ohm} . \mathrm{m}$ at site $11 \mathrm{can}$ be associated to quartzites from the Espinhaco Group. A surficial conductor $(10 \mathrm{ohm} . \mathrm{m})$ saw in the inversion of site 8 was not possible to model in the forward modeling exercise. That conductor is probably associated to the Mesozoic sandstones indicated as Kmc in Fig. 1. Its resistivity value is compatible to sandstone of the same Era (20 ohm.m on average) found in other Brazilian basins as the Parana (Beamish and Travassos, 1992; Stanley et al., 1985) and Solimoes basins (Porsani, 1991).

The conductor of 20-30 ohm.m below the limestone cover 
can be interpreted as the pelitic units of the basin. This conclusion is based on the data from a stratigraphic well 100 $\mathrm{km}$ north of the profile. The well cuts a section of shales and siltites of more than $1 \mathrm{~km}$ of thickness below $300 \mathrm{~m}$ of limestones (Braun et al., 1990). Before this work the whole Bambui Group was estimated to reach up to $2 \mathrm{~km}$ in thickness in the deepest portions of the basin (Braun et al., 1990). Here we found the electrical basement at $2.8-3.0 \mathrm{~km}, 1 \mathrm{~km}$ deeper than the previous estimates based on geological data. Our estimate is in accordance with a recent seismic tomography study that estimated the basement of the basin to lie at $2.8 \mathrm{~km}$ just over $300 \mathrm{~km}$ due south of the studied area (Marchioreto and Assumpcao, 1997).

A high in the basement was modeled below sites 8 and 9. It has possibly the same origin as another high $70 \mathrm{~km}$ to the south identified from gravity data (Lesquer et al., 1981). That structure was later identified as the Sete Lagoas High (SLH) (D’Arrigo et al., 1995). A flexural model for the southern Sao Francisco craton (Ortu, 1990) showed that the $\mathrm{SLH}$ is a result of the load originated during the installation of the Brasilia mobile belt at the western limit of the craton. The high found below sites 8 and 9 probably results from that same mechanism. Under this mechanism the basement rocks would be pushed upwards due to the compressive stress regime. The intense faulting in the region is a result of that same mechanism.

The electrical basement is not uniform being more resistive on its western end, $1000 \mathrm{ohm} . \mathrm{m}$, than elsewhere where it has resistivity of $200 \mathrm{ohm} . \mathrm{m}$. The basement rocks extend to greater depths to about $35 \mathrm{~km}$; less than $10 \mathrm{~km}$ short of the Moho at 43 km (Knize et al., 1984; Berrocal et al., 1989). At the resistive western end the resistive rocks extend down to $70 \mathrm{~km}$, ending at the conductive half-space of $30 \mathrm{ohm} . \mathrm{m}$. Model responses from those depths at the western end are right at the limit of our period range. But there is some indication that the conductor may sink below the resistive rocks, well beyond the known Moho. This is compatible to the inversion of site 5 as it shows the conductor below the resistive rocks.

Another result of this work is the localization of the contact between two crustal blocks: the Brasilia mobile belt and the Sao Francisco craton. That contact is buried below metassediments of the Bambui Group at the Joao Pinheiro fault, indicated with a $\mathrm{J}$ in Fig. 1. The Brasilia mobile belt outcrops $60 \mathrm{~km}$ west of site 5 (Alkimin et al., 1993). Prior to this work that suture zone was thought to lie along the Sao Domingos fault (Thomaz Filho, personal communication, 1998), indicated with a D in Fig. 1, as it is a limit between the folded and unfolded (less affected by orogenesis) Bambui Group.

Apart from the lateral resistivity contrast the modeled upper crust is electrically homogeneous throughout with no evidence of crustal conductors in it. The contact between the resistive upper crust and the lower crust/upper mantle conductor of $30 \mathrm{ohm} . \mathrm{m}$ lies at the limit of the period range; its thickness cannot be resolved within the frequency range. Notwithstanding this lack of resolution the data does require the presence of a strong conductor at lower crust depths.

Crustal conductors are very common throughout the earth's crust (Haak and Hutton, 1986; Schwarz, 1990;
Brown, 1994; Haak et al., 1996). Their presence was modeled in other Brazilian regions as below the Parana basin (Stanley et al., 1985; Beamish and Travassos, 1992) and the Solimoes Basin (Porsani, 1991). Otherwise crustal resistivities of 200-1000 ohm.m are compatible with the figures found in other cratonic regions (Haak and Hutton, 1986; Hyndman and Shearer, 1989; Brown, 1994). Moreover conductors situated below a resistive and homogeneous upper and medium crust with resistivities compatible to ours have been reported extensively in the literature (Simpson, 1998) and are usually explained as a result of the presence of saline fluids, sulfide and graphite.

\section{Conclusions}

This work presents the results from a reconnaissance MT survey in the southern portion of the Sao Francisco sedimentary basin, Brazil. Data were collected along a profile 207 $\mathrm{km}$ long, at seven $500 \mathrm{~m}$ long EMAP-style spreads. This approach allowed for the correction of the static shift distortion and produced 72 -D independently inverted models. Each model is a $500 \mathrm{~m}$ across smooth representation of the regional structure as seen below each site. Those 2-D models were then assembled together in a section to infer any lateral continuity that may exist among them thus producing a first regional model. It is assumed that the continuity section can approximately reproduce the long wavelength features along the profile. Shorter wavelength regional features cannot be adequately reproduced due to site spacing.

We used the model inferred with the continuity section as a first model in a forward 2-D modeling exercise. The objective of the forward modeling was to test and refine the first model. The final 2-D outlined the great sedimentary units and the electrical basement of the Basin. The lower limit for the basin limestone cover (100 ohm.m) was clearly delineated, thickening from west $(300 \mathrm{~m})$ to the east $(800 \mathrm{~m})$. A surficial thin conductive layer of $10 \mathrm{ohm} . \mathrm{m}$ associated to Paleozoic sediments was delineated below sites 09 and 10 . A surficial conductor of $10 \mathrm{ohm} . \mathrm{m}$ at site 8 was associated to the Mesozoic sandstones. The conductor of 20-30 ohm.m below the limestone cover was interpreted as the pelitic units of the basin.

The basement was found at $2.8-3 \mathrm{~km}$ and a high was delineated below sites 8 and 9 . At the more resistive western end of the profile the resistive rocks extend down to $70 \mathrm{~km}$. The $2-$ $\mathrm{D}$ model ends at a conductive half-space of $30 \mathrm{ohm} . \mathrm{m}$. The crustal contact was interpreted as the suture zone between two distinct crustal blocks: the lower Proterozoic rocks of the Brasilia mobile belt and the Archean rocks of the Sao Francisco craton. The contact between these two tectonic units occurs at the Joao Pinheiro Fault extending eastwards the previous knowledge by more than $60 \mathrm{~km}$. Moreover the Brasilia mobile belt crustal block may extends well beyond the previously known Moho in contrast to the craton to the east ending just short of it.

Figure 9 summarizes the geological interpretation based on the 2-D model of Figs. 5, 6 and 7 as well as on a recent geological model (Thomaz et al., 1998). The Joao Pinheiro fault is the contact between the lower Proterozoic rocks of the Brasilia mobile belt and the Archean rocks of the Sao Francisco craton. Figure 9 includes the position of the Moho 

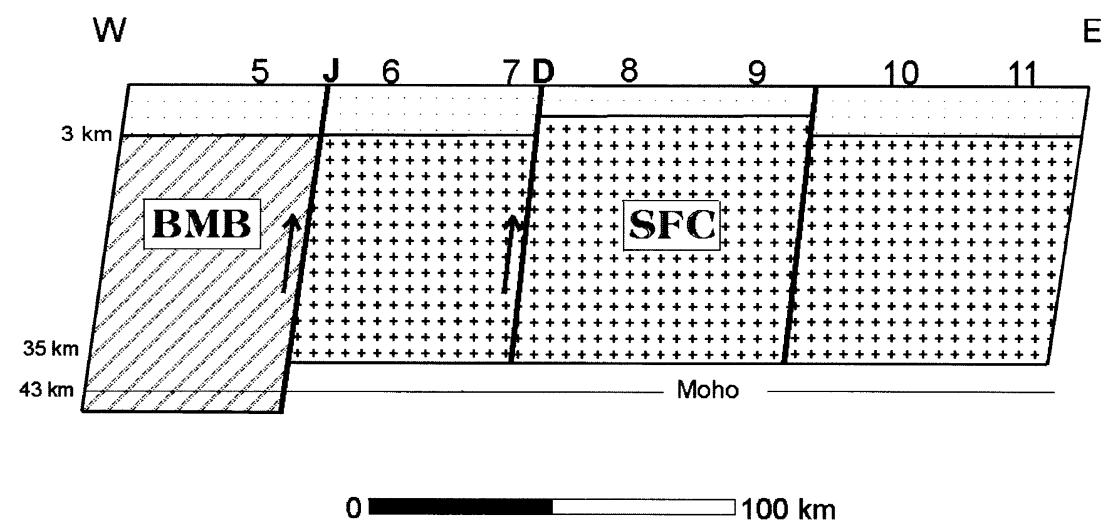

Fig. 9. Geological interpretation of the Sao Francisco Basin. J is the Joao Pinheiro Fault, D is the Sao Domingos Fault. The unmapped fault between sites 9 and 10 is inferred due to the $200 \mathrm{~m}$ high in the basement. The Bambui Group covers both the Brasilia mobile belt (BMB) and the Sao Francisco Craton (SFC). The position of the known Moho is shown in the figure. The vertical scale is arbritary.

as inferred by the refraction seismic (Knize et al., 1984; Berrocal et al., 1989) and the relative movement of the faults (Thomaz et al., 1998).

Acknowledgments. We thank Petrobras for the authorization to use the data set used in this article. JMT was supported by a CNPq scholarship and a grant by VITAE. The authors express their gratitude to Dr. J. L. Porsani who participated in the fieldwork and kindly provided the undecomposed impedance estimates used in this work. PTLM thanks Dr. A. Thomaz Filho for the exciting discussions about the geology of Sao Francisco Basin. The authors acknowledege the helpful suggestions of the two referees of this paper. The support of the above mentioned persons and Institutions does not imply they share the opinions and views expressed in this work by the authors, which are sole responsible for the results shown here.

\section{References}

Alkimin, F. F., B. B. B. Neves, and F. C. Alves, Arcabouco tectonico do craton de Sao Francisco, uma revisao, in III Simposio do Craton do Sao Francisco, pp. 45-62, Salvador, Brazil, 1993 (in Portuguese).

Assumpcao, M., E. P. Fernandes, and J. O. Araujo Filho, Levantamento gravimetrico no Complexo de Barro Alto, GO, resultados preliminares, Revista Brasileira de Geofisica, 3, 17, 1984 (in Portuguese).

Bahr, K.. Geological noise in magnetotelluric data: a classification of distortion types, Phys. Earth Planet. Inter, 66, 24-38, 1991.

Beamish, D. and J. M. Travassos, Magnetotelluric imaging of basalt-covered sediments, First Break, 10, 345-357, 1992.

Beamish, D. and J. M. Travassos, A study of magnetotelluric static distortion in the context of intrusive volcanism, Geophys. Prosp., 41, 61-82, 1993.

Berrocal, J. A., S. Alarcon, and E. Pedreschi, Modelo preliminar da estrutura crusta na regiao proxima ao reservatorio de Sobradinho (BA) atraves do metodo de refracao sismica profunda, Anais CISBGf, Rio de Janeiro, 1, 109, 1989 (in Portuguese).

Blitzkow, D., P. Gasparini, M. S. M. Mantovani, and N. C. Sa, Crustal structures of SE Minas Gerais, Brazil, deduced from gravity measurements, Revista Brasileira de Geociencias, 9, 39-43, 1979.

Braun, O. P. G., Novas contribuicoes a estratigrafia do Grupo Bambui, XXXII Cong. Bras. Geol., Salvador, 1, 159-161, 1982 (in Portuguese).

Braun, O. P. G., U. Mello, and H. D. Della Piazza, Bacias proterozoicas brasileiras com perspectivas exploratorias para hidrocarbonetos, in Origem e Evolucao de Bacias sedimentares, pp. 115-132, PETROBRAS, 1990 (in Portuguese).

Brown, C., Tectonic interpretation of regional conductivity anomalies, Surv. Geophys., 15, 123-157, 1994.

Chave, A. D. and D. J. Thomson, Some comments on magnetotelluric response function estimation, J. Geophys. Res., 94, 14,215-14,225, 1989.

Chave, A. D. and D. J. Thomson, Robust, controlled leverage estimation of magnetotelluric response functions, in Proc. 11th Workshop on Electromagnetic Induction in the Earth, Abstract 8.13, Victoria University, New
Zealand, 1992.

Chave, A. D., D. Thomson, and M. Ander, On the robust estimation of power spectra, coherences, and transfer functions, J. Geophys. Res., 92, 633-648, 1987.

Chouteau, M., P. Zhang, D. J. Dion, B. Giroux, R. Morin, and S. Krivochieva, Delineating mineralization and imaging the regional structure with magnetotellurics in the region of Chibougamau (Canada), Geophys., 62, 730 $748,1997$.

Clarke, J., T. D. Gamble, W. M. Goubau, R. H. Koch, and R. F. Miracky, Remote reference magnetotellurics: equipment and procedures, Geophys. Prosp., 31, 149-170, 1983.

CPRM, Mapa Geologico do Brasil e da area oceanica adjacente incluindo deposito minerais, C. Schobbenhaus, gen. coordinator, CPRM, 1995 (in Portuguese).

D'Arrigo, H. B. P. and F. F. Alkmim, O Alto de Sete Lagoas e sua reativacao, Anais V Simposio Nacional de Estudos Tectonicos, Gramado (RS), Brazil, 21-22, 1995 (in Portuguese).

Dey, A. and H. F. Morrison, Resistivity modeling for arbitrary shaped threedimensional structures, Geophys., 44, 753-780, 1979.

Egbert, G. D. and J. R. Booker, Robust estimation of geomagnetic transfer function, Geophys. J. R. astr. Soc., 87, 173-194, 1986.

Gamble, T. D., W. M. Goubau, and J. Clarke, Magnetotelluric with a remote reference, Geophys., 44, 53-68, 1979.

Groom, R. W. and K. Bahr, Corrections for the near-surface effects: decomposition of the magnetotelluric impedance tensor and scaling corrections for regional resistivities, Surv. Geophys., 13, 341-380, 1992.

Groom, R. W. and R. C. Bailey, Decomposition of magnetotelluric impedance tensors in the presence of local three-dimensional galvanic distortion, J. Geophys. Res., 94, 1913-1925, 1989.

Haak, V. and R. Hutton, Electrical resistivity in the continental lower crust, in Nature of the lower continental crust, Geol. Soc. Spec. Publ., 24, 34-49, 1986.

Haak, V., M. Eisel, G. Nover, J. Stoll, A. Kontny, E. Huenges, U. Harms, and J. Kueck, KTB and the electrical conductivity of the crust, J. Geophys. Res., 102, 18,289-18,306, 1996.

Hyndman, R. D. and P. M. Shearer, Water in the lower continental crust: modeling magnetotelluric and seismic reflection results, Geophys. J. Int., 98, 343-365, 1989.

Jiracek, G. R., Nearsurface and topographic distortion in electromagnetic induction Surveys, Geophys., 11, 163-203, 1990.

Jones, A. G., Static shift of magnetotelluric and its removal in a sedimentary basin environment, Geophys., 53, 967-978, 1988.

Knize, S., J. A. Berrocal, and D. M. Oliveira, Modelo preliminar de velocidades sismicas de crosta atraves de explosoes locais registradas pela rede sismografica de sobradinho BA, Revista Brasileira de Geofisica, 2, 95-104, 1984 (in Portuguese).

Larsen, J. C., Transfer functions: smooth robust estimates by least squares and remote reference methods, Geophys. J. Int., 99, 645-663, 1989.

Larsen, J. C., R. L. Mackie, A. Manzella, A. Fiordelisi, and S. Rieven, Robust smooth MT transfer functions, Geophys. J. Int., 124, 801-819, 1996.

Lesquer, A., F. F. M. Almeida, A. Davino, J. C. Lachaud, and P. Maillard, 
Signification structurale des anomalies gravimetriques de la partie sud du Craton Sao Francisco (Bresil), Tectonophysics, 76, 273-293, 1981.

Mackie, R. L, T. R. Madden, and P. E. Wannamaker, Three-dimensional magnetotelluric modeling using difference equations theory and comparisons to integral equations, Geophys., 58, 215-226, 1993.

Marchioreto, A. and M. Assumpcao, Inversao tomografica com ondas Rayleigh no sul do Craton do Sao Francisco e Faixa de dobramentos Brasilia-Uruacu, Anais 5 Cong. Int. Soc. Bras. Geofisica, 2, 983-986, 1997 (in Portuguese).

Murray, G. E., M. J. Kaczor, and R. E. Macarthur, Indigenous pre-cambrian petroleum revisited, AAPG Bull., 64, 1681-1700, 1980.

Ortu, J. C., Modelagem tectonofisica da porcao sul da Bacia do Sao Francisco, MG, M.Sc. Thesis, UFOP, 148 pp., Ouro Preto, 1990 (in Portuguese).

Pellerin, L. and G. W. Hohmann, Transient electromagnetic inversion, a remedy for magnetotelluric static shifts, Geophys., 55, 1242-1250, 1990.

Porsani, J. L., Estudo da estrutura geoeletrica da regiao do Jurua, M.Sc. Thesis, UFPa, 102 pp., 1991 (in Portuguese).

Porsani, J. L. and S. L. Fontes, Estudo magnetotelurico na Bacia do Sao Francisco, Relatorio PETROBRAS/CENPES/SEGEF, 30 pp., 1993 (in Portuguese).

Schwarz, G., Electrical condutivity of the earth's crust and upper mantle, Surv. Geophys., 11, 133-161, 1990.

Simpson, F., Stress and seismicity in the lower continental crust: a challenge to simple ductility and implications for electrical conductivity mechanim, in Anals of the 14th Workshop on Electromagnetic Induction in the Earth, pp. 215-228, Sinaia, 1998.

Smith, J. T. and J. R. Booker, Rapid inversion of two and three-dimensional magnetotelluric data, J. Geophys. Res., 96, 3905-3922, 1991.

Stanley, W. D., A. R. Saad, and W. Ohofugi, Regional magnetotelluric surveys in hydrocarbon exploration, Parana Basin, Brazil, Bull. AAPG, 69, 346-360, 1985.

Sutarno, D. and K. Vozoff, Phase-smoothed robust M-estimation of magnetotelluric impedance functions, Geophys., 36, 938-942, 1991.
Thomaz Filho, A., K. Kawashita, and U. G. Cordani, A origem do Grupo Bambui no contexto da evolucao geotectonica e idades radiometricas, Anais da Academia Brasileira de Ciencias, 78, 527-548, 1998 (in Portuguese).

Torres-Verdin, C. and F. X. Bostick, Jr., Implications of the Born approximation for the magnetotelluric problem in three-dimensional environments, Geophys., 57, 587-602, 1992a.

Torres-Verdin, C. and F. X. Bostick, Jr., Principles of spatial surface electric field filtering in magnetotellurics: electromagnetic array profiling (EMAP), Geophys., 57, 603-622, 1992 b.

Ussami, N., Interpretation of the gravity anomalies of Bahia state (Brazil), Ph.D. Thesis, University of Durham, 234 pp., 1986.

Ussami, N., Estudos geofisicos no Craton do Sao Francisco: estagio atual e perspectivas futuras, in III Simposio do Craton do Sao Francisco, pp. 3543, Salvador, Brazil, 1993 (in Portuguese).

Valeriano, C. M., Evolucao tectonica da extremidade meridional da faixa Brasilia, regiao da represa de Furnas, sudoeste de Minas Gerais, Ph.D. Thesis, Instituto de Geociencias USP, 198 pp., Sao Paulo, Brazil, 1992 (in Portuguese).

Wannamaker, P. E., Advances in three-dimensional magnetotelluric modeling using integral equations, Geophys., 56, 1716-1728, 1991.

Wannamaker, P. E., G. W. Hohmann, and W. A. San Filipo, Electromagnetic modeling of 3-D bodies in layered earth using integral equations, Geophys., 49, 60-74, 1984.

Wannamaker, P. E., J. A. Stodt, and L. Rijo, A stable finite element solution for two-dimensional magnetotelluric modeling, Geophys. J. R. astr. Soc., 88, 277-296, 1987.

Wu, N., J. R. Booker, and T. Smith, Rapid two-dimensional inversion of Coprod2 data, J. Geomag. Geoelectr., 45, 1073-1087, 1993.

J. M. Travassos (e-mail: jandyr@on.br) and P. T. L. Menezes (e-mail: ptarso@uerj.br) 